\title{
Zastosowanie ultrasonografii przezczaszkowej typu duplex w diagnostyce chorób pozapiramidowych
}

\section{Transcranial sonography in diagnosis of movement disorders}

Woiciech Ambrosius, Woiciech Kozubski

Katedra i Klinika Neurologii, Uniwersytet Medyczny im. Karola Marcinkowskiego w Poznaniu

Neurologia i Neurochirurgia Polska 2010; 44, 6: 574-579

\section{Streszczenie}

Rutynowo stosowane metody obrazowania układu nerwowego, takie jak tomografia komputerowa i tomografia rezonansu magnetycznego, służą głównie do wykluczania wtórnych przyczyn schorzeń pozapiramidowych. Nie są jednak istotnie przydatne w wykrywaniu zmian w obrębie jąder podstawy i pnia mózgu, szczególnie we wczesnym okresie wystąpienia objawów idiopatycznych postaci tych chorób.

Ostatnio podjęto próby stosowania przezczaszkowej ultrasonografii metodą duplex w diagnostyce obrazowej jąder podstawy. Metoda ta, z powodzeniem wykorzystywana w chorobach naczyń mózgu, pozwala także uwidocznić niektóre struktury miąższowe mózgowia. W pracy przedstawiono najważniejsze odkrycia dotyczące obserwowanych w badaniu ultrasonograficznym zaburzeń określonych struktur, w szczególności hiperechogeniczności w obrębie istoty czarnej towarzyszącej chorobie Parkinsona.

Słowa kluczowe: ultrasonografia przezczaszkowa, choroby pozapiramidowe, choroba Parkinsona.

Zespoły pozapiramidowe obejmują istotną część schorzeń zwyrodnieniowych ośrodkowego układu nerwowego - do najważniejszych z nich należą: choroba Parkinsona, atypowe zespoły parkinsonowskie, dystonie, drżenie samoistne i zespół niespokojnych nóg. Szacuje się, że idiopatyczna postać choroby Parkinsona

\begin{abstract}
Conventional methods of neuroimaging, such as computed tomography and magnetic resonance imaging, are mostly useful in exclusion of movement disorders with secondary aetiology. Recently, the application of transcranial sonography has been introduced to the diagnosis of extrapyramidal diseases. This valuable technique, with proven usefulness in the field of cerebrovascular events, may reveal some brain parenchymal structures. In this review the most important findings of ultrasonographic abnormalities in the brain, particularly hyperechogenicity of substantia nigra in Parkinson disease, are presented.
\end{abstract}

Key words: transcranial ultrasonography movement disorders, Parkinson disease.

dotyka $1 \%$ osób powyżej 65 . roku życia (3\% powyżej 75. roku życia), a zapadalność wynosi 8-18 przypadków na 100000 osób w ciągu roku [1,2]. Dwie ostatnie jednostki to najczęściej występujące choroby pozapiramidowe - drżenie samoistne występuje 20 razy częściej niż choroba Parkinsona [3], a zespół niespokojnych nóg

Adres do korespondencii: Wojciech Ambrosius, Katedra i Klinika Neurologii Uniwersytetu Medycznego im. Karola Marcinkowskiego w Poznaniu, ul. Przybyszewskiego 49, 60-355 Poznań, tel. +48 61869 15 35, faks + 486186916 97, e-mail: wambrosius@ump.edu.pl Prace otrzymano: 12.05.2010; przyięto do druku: 27.07.2010 
dotyczy od 3\% do 29\% osób [4]. Tak duży rozrzut wyników badań epidemiologicznych wynika m.in. stąd, że dla tych chorób nie udało się znaleźć jednego znacznika diagnostycznego, co więcej, istnieją także rozbieżności w sformułowaniu niebudzących wątpliwości ('twardych') kryteriów, które pomogłyby ustalić właściwe, ostateczne rozpoznanie.

Wydaje się, że najbardziej istotnym zagadnieniem jest postawienie diagnozy we wczesnym okresie choroby, a dobrym tego przykładem jest choroba Parkinsona w badaniach, w których rozpoznanie kliniczne skonfrontowano z badaniem sekcyjnym, okazało się, że błędna diagnoza dotyczyła od $10 \%$ do $20 \%$ pacjentów $[5,6]$.

Wysitki wielu badaczy zajmujących się schorzeniami układu pozapiramidowego koncentrują się więc na poszukiwaniu jednoznacznych wskazówek diagnostycznych. W ostatnich latach, oprócz badań na poziomie molekularnym, dynamicznie rozwijającą się dziedziną jest diagnostyka obrazowa. Niestety, powszechnie stosowane klasyczne techniki tomografii komputerowej i rezonansu magnetycznego (RM) sa bardziej pomocne w wykluczaniu wtórnych przyczyn zespołów pozapiramidowych (procesów nowotworowych, wodogłowia, ognisk niedokrwiennych i krwotocznych) - we wczesnej fazie chorób idiopatycznych ich wyniki są prawidłowe.

Znacznie bardziej obiecujące okazują się nowoczesne techniki diagnostyczne: obrazowanie $\mathrm{RM} z$ analiza wolumetryczną, RM tensora dyfuzji oraz badania tomo- grafii emisyjnej pojedynczego fotonu (single photon emission computed tomography - SPECT) i pozytonowej tomografii emisyjnej (positron emission tomography - PET). Szczególnie te ostatnie, obrazujące zmiany biochemiczne układu nigrostriatalnego i zmniejszenie liczby neuronów dopaminergicznych, mogą być użyteczne w różnicowaniu wczesnych postaci typowego i atypowego parkinsonizmu [7-9]. Dostęp do tego typu neuroobrazowania jest jednak ograniczony i nawet w krajach wysoko rozwiniętych sa to techniki rzadko stosowane $\mathrm{w}$ rutynowej diagnostyce neurologicznej.

Należy pamiętać, że postęp techniczny ostatnich kilkunastu lat dotyczy również metod ultrasonograficznych. Znajdują one zastosowanie głównie w diagnostyce schorzeń naczyniowych ośrodkowego układu nerwowego. Nie jest natomiast powszechnie wiadome, że aparaty wysokiej rozdzielczości pozwalają uzyskać ultrasonograficzne, dwuwymiarowe odwzorowanie wybranych struktur mózgowia: pnia mózgu, wzgórza i innych jąder podstawy, także rogów przednich komór bocznych, komory trzeciej oraz niektórych struktur móżdżku. Fakt, że dzięki ultrasonografii przezczaszkowej można uwidocznić wymienione struktury, przyczynił się do zainteresowania tą techniką badaczy zajmujących się schorzeniami pozapiramidowymi.

W 1995 r. ukazało się doniesienie naukowe, w którym wykazano, że u $70 \%$ z 30 osób z chorobą Parkinsona występowało zwiększenie intensywności sygnału

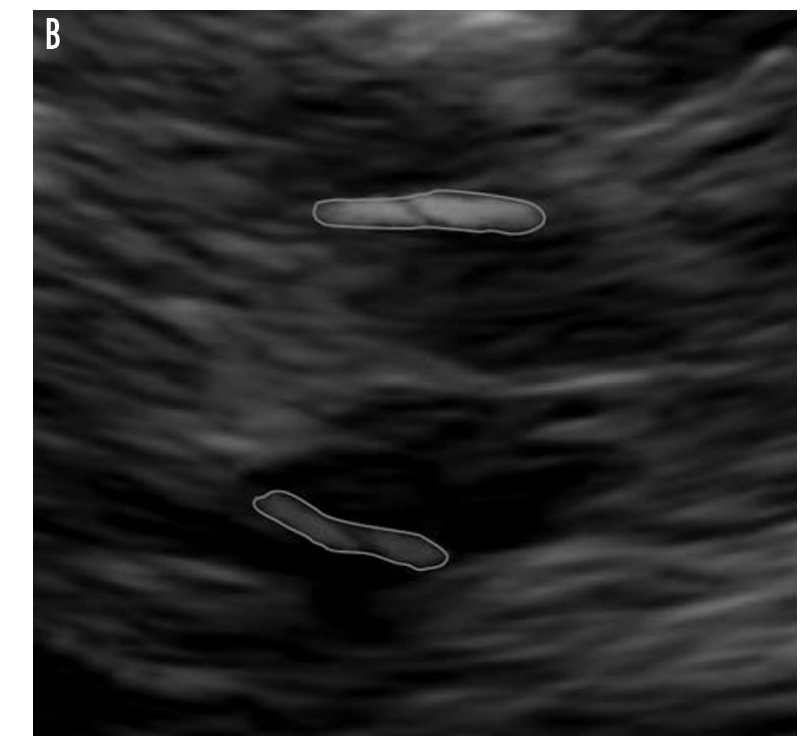

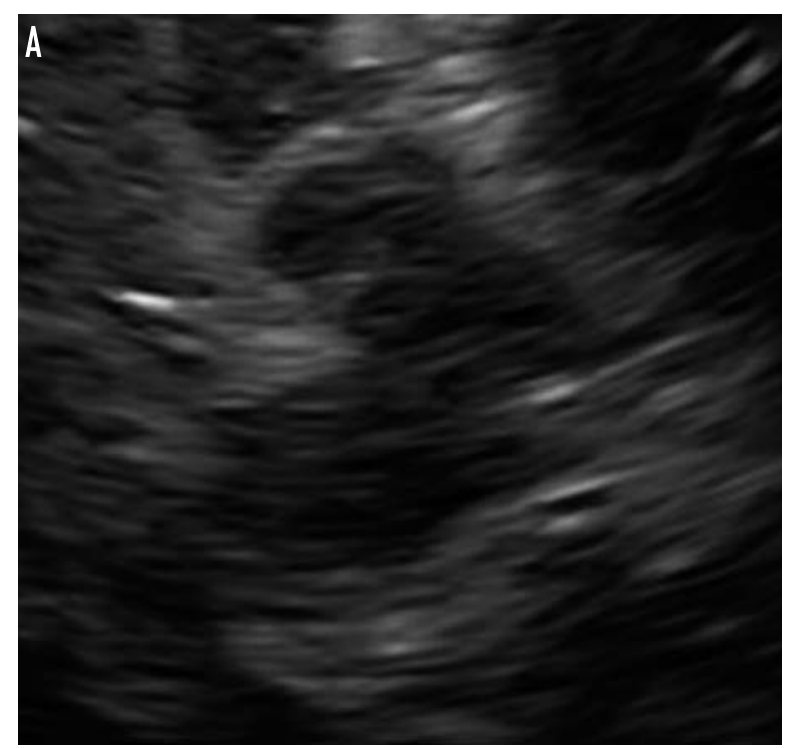

Ryc. 1. Pień mózgu zobrazowany za pomoca ultrasonografii przezczaszkowej: (A) u osoby zdrowei; (B) u osoby z chorobq̨ Parkinsona widoczne podwyżzzenie sygnału w rzucie odpowiadającym położeniu istoty czarnej (obrys linią ciagłą) (zbiory własne autorów)

Fig. 1. Brain stem in transcranial ultrasonography: (A) in a healthy person; (B) in patient with Parkinson disease, area of hyperechogenicity corresponds to substantia nigra location (marked by continuous line) 
ultradźwiękowego (hiperechogeniczność) istoty czarnej (ryc. 1.), podczas gdy to samo zaburzenie zaobserwowano tylko u 2 z 30 osób ze zdrowej grupy kontrolnej [10].

Kilka lat później ta sama grupa badaczy opublikowała wyniki badania przeprowadzonego na większej populacji - hiperechogeniczność istoty czarnej występowała u $91 \%$ osób z chorobą Parkinsona, przy czym znamiennie częściej taki obraz dotyczył struktury leżącej po przeciwnej stronie w odniesieniu do objawów klinicznych schorzenia [11]. Określono także wartości referencyjne pomiarów echogeniczności istoty czarnej dla grupy kontrolnej średni pomiar wyniósł $0,12 \mathrm{~cm}^{2}$, podczas gdy dla osób z chorobą Parkinsona był równy $0,25 \mathrm{~cm}^{2}$, przy czym u 94 ze 103 osób z grupy badanej pomiary przekraczały $0,19 \mathrm{~cm}^{2}$. Wartości z przedziału $0,20-0,24 \mathrm{~cm}^{2}$ traktowano jako graniczne [11].

Pojawiła się więc szansa zastosowania relatywnie taniej, bezpiecznej i dostępnej metody obrazowej, która pomogłaby w diagnostyce schorzeń jąder podstawy tym bardziej że w tym badaniu wykorzystuje się klasyczne skroniowe okno akustyczne oraz typową głowicę sektorową o częstotliwości 1,6-3,5 MHz, tę samą, której używa się do oceny tętnic wewnątrzczaszkowych. Poza tym, co we współczesnych aparatach nie jest istotnym problemem, powinna istnieć możliwość regulacji ustalenia głębokości próbkowania na $14-16 \mathrm{~cm}$, natężenia sygnału ok. $45 \mathrm{~dB}$ oraz redukcji sygnałów o niskim echu i regulacji jasności obrazu [12].

Jak wspomniano wcześniej, przy nowo rozwijających się objawach klinicznych, poważnym problemem może być ustalenie prawidłowego rozpoznania choroby Parkinsona. Tym bardziej że w początkowym okresie atypowych zespołów pozapiramidowych standardowe leczenie przeciwparkinsonowskie okazuje się niekiedy skuteczne.

W dwóch niezależnych badaniach wykazano, że w diagnostyce różnicowej wymienionych schorzeń ultrasonografia przezczaszkowa może okazać się bardzo pomocna. W pierwszym $z$ nich porównano grupę 16 chorych na zanik wieloukładowy, $9 \mathrm{z}$ postępującym porażeniem nadjądrowym oraz 25 osób z chorobą Parkinsona. Okazało się, że wśród tych ostatnich hiperechogeniczność istoty czarnej występowała w 96\%, a zaledwie u $9 \%$ osób z parkinsonizmem atypowym [13]. Z kolei w obserwacji przeprowadzonej na większej grupie (102 osoby z chorobą Parkinsona, 34 chorych na zanik wieloukładowy i 21 chorych na postępujące porażenie nadjądrowe) różnica ta nie była już tak duża (hiperechogeniczność występowała odpowiednio u 89\%, 25\% i 39\% osób z wymienionych grup), niemniej nadal znamiennie istotna [14]. Niekiedy różnicowanie kliniczne pomiędzy chorobą Parkinsona a drżeniem samoistnym bywa także niełatwe i w takich przypadkach wskazówki może przynieść badanie za pomocą ultrasonografii przezczaszkowej. Niehaus porównał częstość występowania hiperechogeniczności istoty czarnej w obu schorzeniach. Okazało się, że objaw ten występował aż u 93\% osób z chorobą Parkinsona i tylko u $10 \%$ chorych na drżenie samoistne [15].

Kolejnym krokiem w ocenie znaczenia odchyleń stwierdzanych w badaniu ultrasonografii przezczaszkowej było przeprowadzenie badań prospektywnych oceniających potencjalne zmiany rozmiaru hiperechogeniczności istoty czarnej wraz z nasileniem objawów klinicznych. W jednym z projektów, pięcioletniej obserwacji poddano niewielką grupę 27 osób z chorobą Parkinsona. Wyniki tej pracy pokazują, że postępowi schorzenia (stan kliniczny oceniano m.in. skalami Hoehn i Yahra oraz UPDRS) nie towarzyszyło zwiększenie powierzchni o podwyższonej echogeniczności istoty czarnej [16].

Stanowiło to podstawę do rozważań, co może być przyczyną hiperechogeniczności istoty czarnej obserwowanej w ultrasonografii przezczaszkowej - dotąd nie ma jednoznacznej odpowiedzi. Najbardziej prawdopodobna jest hipoteza, która mówi, że jest to być może rezultat kumulacji żelaza w obrębie tej struktury, co znalazło potwierdzenie w badaniach zarówno eksperymentalnych na zwierzętach, jak i post mortem [17]. Jest to również zgodne z przekonaniem o istotnej roli zaburzeń gospodarki jonami żelaza $w$ chorobach neurodegeneracyjnych, w tym także w chorobie Parkinsona [18]. Teorię, że wzmożona echogeniczność istoty czarnej stanowi wynik gromadzenia się żelaza, uwiarygodniają pośrednio obserwacje występowania tego zjawiska w innej chorobie neurologicznej, w etiopatogenezie której także wskazuje się na rolę żelaza, mianowicie w stwardnieniu rozsianym [19].

$\mathrm{Z}$ drugiej strony, analizując dostępne publikacje dotyczące omawianego zagadnienia, widać, że hiperechogeniczność istoty czarnej nie jest objawem swoistym dla choroby Parkinsona - obecność tego objawu stwierdza się średnio u ok. 9\% osób zdrowych [20]. Zaobserwowano jednak, że u $60 \%$ zdrowych osób poniżej 40. roku życia, u których w badaniu za pomocą ultrasonografii przezczaszkowej wykryto patologię istoty czarnej, w pozytonowej tomografii emisyjnej występuje charakterystyczne dla zaburzenia w obrębie układu nigrostriatalnego zmniejszenie wychwytu ${ }^{18} \mathrm{~F}$-dopy przez prążkowie [20].

Wszystko to skłania do teorii, którą zgodnie głoszą badacze zajmujący się tym zagadnieniem, że nieprawi- 
dłowy obraz ultrasonograficzny istoty czarnej jest raczej wskaźnikiem mówiącym o predylekcji do wystąpienia choroby Parkinsona, a nie markerem jej postępu. Taki pogląd znajduje swoje uzasadnienie w dwóch istotnych badaniach. Do pierwszego kwalifikowano osoby powyżej 60. roku życia, które prezentowały dyskretne objawy dysfunkcji układu pozapiramidowego i jednocześnie nie spełniały kryteriów rozpoznania choroby Parkinsona (np. izolowane spowolnienie lub drżenie bądź sztywność mięśniowa). Okazało się, że osoby z podwyższoną echogenicznością istoty czarnej gorzej wykonywały typowe testy oceniające funkcje ruchowe (tzw. finger tapping) [21]. Z kolei w innym badaniu, przeprowadzonym na stuosobowej grupie chorych z zaburzeniami psychopatologicznymi i przez to pobierającymi leki neuroleptyczne, wykazano, że objawy niepożądane farmakoterapii (szczególnie zespół pozapiramidowy) występowały istotnie częściej wśród pacjentów ze stwierdzaną w ultrasonografii przezczaszkowej hiperechogenicznością istoty czarnej [22]. Wreszcie, najbardziej interesujące wydają się wyniki opublikowanego w 2008 r. badania prospektywnego ze ślepą próbą, którym objęto 60 pacjentów z zespołem parkinsonowskim, o nie do końca jasnym obrazie klinicznym. U wszystkich osób na początku rocznej obserwacji wykonano ocenę struktur pnia za pomocą ultrasonografii przezczaszkowej, a dodatkowo także, zgodnie z zaleceniami zespołów eksperckich, neuroobrazowanie metodą SPECT (z oceną transportera dopaminy - DAT) oraz PET z rakloprydem. Po 12 miesiącach badania niezależni badacze (którzy nie znali wyniku oceny ultrasonograficznej) ustalili ostateczne rozpoznanie - u 39 stwierdzono idiopatyczną chorobę Parkinsona. Okazało się, że w odniesieniu do punktu końcowego badania (a więc rozpoznania samoistnej postaci choroby Parkinsona po rocznej obserwacji) czułość i swoistość badania TCS okazały się bardzo dobre - wyniosły odpowiednio 90,7\% i 82,4\% [23].

$\mathrm{Na}$ potencjalny związek pomiędzy nieprawidłowym ultrasonograficznym obrazem istoty czarnej a predyspozycją do wystąpienia choroby Parkinsona pośrednio wskazują także obserwacje rodzin osób z tym schorzeniem. Aż u 45\% zdrowych krewnych pierwszego stopnia zwiększona echogeniczność istoty czarnej wiązała się $\mathrm{z}$ zaburzeniem funkcjonowania układu nigrostriatalnego wykazanym badaniem PET [24]. Obiecujące rezultaty szeregu prac wskazujących na potencjalną użyteczność ultrasonografii przezczaszkowej w wykrywaniu choroby Parkinsona we wczesnym okresie były inspiracją próby jej wykorzystania w innych schorzeniach neurologicznych.
Skoro postuluje się, że hiperechogeniczność istoty czarnej może mieć związek z patologicznym gromadzeniem się jonów żelaza, postanowiono sprawdzić, czy istnieją nieprawidłowości obrazu tej struktury w zespole niespokojnych nóg, który częstokroć kojarzy się z niedokrwistością niedoborową tego pierwiastka. Praktycznie rozpoznanie zespołu niespokojnych nóg ustala się na podstawie badania podmiotowego, nie istnieją żadne obiektywnie stwierdzane zaburzenia, zarówno w ocenie stanu przedmiotowego, jak i w badaniach obrazowych. W niedawno opublikowanym doniesieniu porównano 50 osób z zespołem niespokojnych nóg ze zdrową grupą kontrolną, dobraną odpowiednio do płci i wieku [25]. Wykryto, że w przypadku tego zespołu występuje zmniejszenie echogeniczności istoty czarnej - suma obustronnych pomiarów powierzchni sygnału z istoty czarnej nigdy nie przekraczała wartości $0,2 \mathrm{~cm}^{2}$, co oznacza, że pomiar sygnału z istoty czarnej po jednej stronie nie przekraczał $0,11 \mathrm{~cm}^{2}$. Hipoechogeniczność istoty czarnej charakteryzowała ponad $90 \%$ pacjentów z idiopatyczną i $60 \%$ chorych z wtórną postacią zespołu niespokojnych nóg.

Z kolei w przypadku choroby Wilsona zaobserwowano, że hiperechogeniczność istoty czarnej występowała co prawda jedynie u połowy pacjentów, ale za to u prawie wszystkich stwierdzono wzmożenie echogeniczności jąder soczewkowatych; dodatkowo objawy ultrasonograficzne korelowały $\mathrm{z}$ zaawansowaniem klinicznym schorzenia [26]. Co ciekawe, wg niektórych teorii, zaburzenia metabolizmu miedzi, będące istotą wymienionego powyżej schorzenia, są także odpowiedzialne za gromadzenie się tego mikroelementu w jądrach podstawy w przebiegu dystonii ogniskowej. Być może dlatego u ponad połowy pacjentów z kręczem karku lub kurczem pisarskim stwierdzono obszar o zwiększonej echogeniczności w obrębie środkowej części jądra soczewkowatego po stronie przeciwnej w stosunku do objawów dystonicznych [27].

Dostępne są także wyniki pojedynczych badań nad oceną ultrasonograficzną mózgowia w takich genetycznie uwarunkowanych schorzeniach pozapiramidowych, jak choroba Huntingtona i ataksja rdzeniowo-móżdżkowa. W przypadku tej pierwszej wzmożenie echogeniczności dotyczyło nie tylko istoty czarnej ( $40 \%$ chorych), ale także jądra ogoniastego (13\% chorych) [28]. Z kolei u ponad połowy chorych $\mathrm{z}$ ataksją rdzeniowo-móżdżkową typu 3 występowało zwiększenie echogeniczności jądra zębatego $\mathrm{i}$ istoty białej w obrębie móżdżku, czego nie obserwowano w grupie kontrolnej osób zdrowych [29]. 


\section{Podsumowanie}

Wykorzystanie ultrasonografii przezczaszkowej do oceny innych niż naczynia struktur mózgowia zdobywa coraz więcej zwolenników. Co oczywiste, nie jest ona alternatywą dla takich badań obrazowych, jak tomografia rezonansu magnetycznego czy SPECT, lecz ich cennym uzupełnieniem. Pamiętać należy o jej głównych ograniczeniach - zależności od jakości okna kostnego (które niekiedy całkowicie uniemożliwia wizualizację struktur wewnątrzczaszkowych), a przede wszystkim od doświadczenia ultrasonografisty. Z kolei główne zalety (niskie koszty, łatwy dostęp, nieinwazyjność) mogą przyczynić się do jej szerszego zastosowania w diagnostyce różnicowej chorób pozapiramidowych. Szczególnie interesujące wydają się pomysły nad zastosowaniem tej metody w wykrywaniu choroby Parkinsona przed wystąpieniem objawów ruchowych. Możemy być pewni, że w niedalekiej przyszłości poznamy rezultaty obserwacji przeprowadzonych na dużych populacjach chorych.

\section{Oświadczenie}

Autorzy zgłaszają brak konfliktu interesów.

\section{Piśmiennictwo}

1. de Rijk M.C., Breteler M.M., Graveland G.A. i wsp. Prevalence of Parkinson's disease in the elderly: the Rotterdam Study. Neurology 1995; 45: 2143-2146.

2. de Lau L.M., Breteler M.M. Epidemiology of Parkinson's disease. Lancet Neurol 2006; 5: 525-535.

3. Louis E.D., Ottman R., Hauser W.A. How common is the most common adult movement disorder? Estimates of the prevalence of essential tremor throughout the world. Mov Disord 1998; 13: 5-10.

4. Schrag A. Epidemiology of movement disorders. W: Jankovic J.T., Tolosa E. [red.]. Parkinson's disease and movement disorders. Wyd. 5. Lippincott Williams \& Wilkins, Philadelphia 2007, ss. 61-62.

5. Hughes A.J., Daniel S.E., Lees A.J. Improved accuracy of clinical diagnosis of Lewy body Parkinson's disease. Neurology 2001; 57: 1497-1499.

6. Litvan I., MacIntyre A., Goetz C.G. i wsp. Accuracy of the clinical diagnoses of Lewy body disease, Parkinson disease, and dementia with Lewy bodies: a clinicopathologic study. Arch Neurol 1998; 55: 969-978.

7. Booij J., Speelman J.D., Horstink M.W. i wsp. The clinical benefit of imaging striatal dopamine transporters with [123I]FPCIT SPET in differentiating patients with presynaptic parkinsonism from those with other forms of parkinsonism. Eur J Nuclear Med 2001; 28: 266-272.
8. Huang W.S., Chiang Y.H., Lin J.C. i wsp. Crossover study of (99m)Tc-TRODAT-1 SPECT and (18)F-FDOPA PET in Parkinson's disease patients. J Nucl Med 2003; 44: 999-1005.

9. Piccini P., Whone A. Functional brain imaging in the differential diagnosis of Parkinson's disease. Lancet Neurol 2004; 3: 284290.

10. Becker G., Seufert J., Bogdahn U. i wsp. Degeneration of substantia nigra in chronic Parkinson's disease visualized by transcranial color-coded real-time sonography. Neurology 1995; 45: 182-184.

11. Berg D., Siefker C., Becker G. Echogenicity of the substantia nigra in Parkinson's disease and its relation to clinical findings. J Neurol 2001; 248: 684-689.

12. Puls I., Berg D., Maurer M. i wsp. Transcranial brain parenchyma sonography in movement disorders: state of the art. Ultrasound Med Biol 2007; 1: 15-25.

13. Walter U., Niehaus L., Probst T. i wsp. Brain parenchyma sonography discriminates Parkinson's disease and atypical parkinsonian syndromes. Neurology 2003; 60: 74-77.

14. Behnke S., Berg D., Naumann M. i wsp. Differentiation of Parkinson's disease and atypical parkinsonian syndromes by transcranial ultrasound. J Neurol Neurosurg Psychiatry 2005; 76: 423-425.

15. Niehaus L., Savyer N., Weber U. i wsp. Brain parenchyma sonography in patients with essential tremor and Parkinson's disease. Cerebrovasc Dis 2004; 17 (supl. 4): 3.

16. Berg D., Merz B., Reiners K. i wsp. Five-year follow-up study of hyperechogenicity of the substantia nigra in Parkinson's disease. Mov Disord 2005; 20: 383-385.

17. Berg D. Disturbance of iron metabolism as a contributing factor to SN hyperechogenicity in Parkinson's disease: implications for idiopathic and monogenetic forms. Neurochem Res 2007; 32 : 1646-1654.

18. Ke Y., Ming Qian Z. Iron misregulation in the brain: a primary cause of neurodegenerative disorders. Lancet Neurol 2003; 2: 246-253.

19. Walter U., Wagner S., Horowski S. i wsp. Transcranial brain sonography findings predict disease progression in multiple sclerosis. Neurology 2009; 73: 1010-1017.

20. Berg D., Becker G., Zeiler B. i wsp. Vulnerability of the nigrostriatal system as detected by transcranial ultrasound. Neurology 1999; 53: 1026-1031.

21. Berg D., Siefker C., Ruprecht-Dörfler P. i wsp. Relationship of substantia nigra echogenicity and motor function in elderly subjects. Neurology 2001; 56: 13-17.

22. Jabs B.E., Bartsch A.J., Pfuhlmann B. Susceptibility to neuroleptic-induced parkinsonism - age and increased substantia nigra echogenicity as putative risk factors. Eur Psychiatry 2003; 18: 177-181.

23. Gaenslen A., Unmuth B., Godau J. i wsp. The specificity and sensitivity of transcranial ultrasound in the differential diagnosis of Parkinson's disease: a prospective blinded study. Lancet Neurol 2008; 7: 417-424.

24. Ruprecht-Dörfler P., Berg D., Tucha O. i wsp. Echogenicity of the substantia nigra in relatives of patients with sporadic Parkinson's disease. NeuroImage 2003; 18: 416-422. 
25. Godau J., Schweitzer K.J., Liepelt I. i wsp. Substantia nigra hypoechogenicity: definition and findings in restless legs syndrome. Mov Disord 2007; 22: 187-192.

26. Walter U., Krolikowski K., Tarnacka B. i wsp. Sonographic detection of basal ganglia lesions in asymptomatic and symptomatic Wilson disease. Neurology 2005; 64: 1726-1732.

27. Becker G., Berg D., Francis M. i wsp. Evidence for disturbances of copper metabolism in dystonia: from the image towards a new concept. Neurology 2001; 57: 2290-2294.

28. Postert T., Lack B., Kuhn W. i wsp. Basal ganglia alterations and brain atrophy in Hunington's disease depicted by transcranial real time sonography. J Neurol Neurosurg Psychiatry 1999; 67: 457-462.

29. Postert T., Eyding J., Berg D. i wsp. Transcranial sonography in spinocerebellar ataxia type 3. J Neural Transm Suppl 2004; 68: 123-133 